\title{
浅议天然气输气站场的消防安全管理工作
}

祝原林

DOI:10.32629/btr.v3i5.3160

[摘 要] 众所周知, 烃类物质具有易燃、易爆特性, 天然气输气站场在运行过程中,易发生火灾爆炸事故,故加强天然气站场的消防安全管理异常 重要。文章综合分析天然气站场内消防安全管理存在的难点与问题,探讨消防安全工作顺利进行的措施与策略。

[关键词] 天然气站场; 消防安全管理; 措施

\section{1 天然气站场消防安全管理的必要性}

管道作为目前天然气输送的主要渠道, 被誉为五种运输方式之一, 天 然气管道广泛应用于城市发展、能源供应、石油化工的基础设施和人们生 活的基础条件等领域。天然气管道在国民经济中占有极其重要的战略地位, 被誉为国家重大生命线。在这条生命线上, 天然气输气站场即为其中的关 键点。天然气输气站场是输气管道工程中各类工艺站场的总称。其主要功 能是接收天然气、给管道天然气增压、分输天然气、配气、储气调峰、发 送和接收清管器等。

天然气输送是一个很复杂的过程, 站场的正常生产运行是保证天然气 安全输送的基础, 由于天然气的主要成分是烃类碳氢化合物, 具有易燃、易 爆、易聚集静电等特性, 而整个输送过程是在特定的条件下进行, 故具有较 大的火灾及爆炸危险性, 特别是输气站场存在设备多、工艺相对复杂、动 静密封点多等特点, 具有极大的火灾爆炸隐患。一旦发生事故, 可能造成巨 大的经济损失和人员伤亡, 并带来恶劣的社会影响。因此, 分析天然气输气 站场存在的火灾危险性因素, 制定相应的预防措施, 控制火灾爆炸事故的 发生, 是天然气行业安全生产的一个重要课题。

\section{2 提高天然气输气站场消防安全管理的措施}

消防安全管理具有自然性、社会性、全过程性和技术性等特征。因此 强化对各类设备及消防系统的管理, 落实安全生产责任, 提高全员安全生 产意识和技能, 执行落实好各项规章制度和消除思想认识上的误区无疑是 实现安全生产 “有序可控” 良好局面的有效办法。对于提高天然气站场的 消防管理水平, 主要需要从以下几个方面努力。

2.1加强生产设备及消防系统的安全管理

提高对生产设备和消防系统安全管理对保障天然气站场的消防安全 有举足轻重的作用。如何保证设备及系统的安全呢? 对于基层生产单位主 要应从以下两方面努力。(1)加强对设备的检查和维护保养力度, 及时排查 问题和隐患。设备安全管理可以通过日常的检查和建立安全档案来完成。 设备档案的建立是其主要依据的来源：设备的正确管理、操作和使用, 档 案内容应包括安全设施的适用范围以及安全设施的所有详细资料和维护 检修以及设施的使用情况的记录等。通过档案可以有效的发现设备存在的 问题及不足。(2)采用消防联动一体化控制系统。消防联动一体化控制系统 是指当确认火灾发生后, 通过联动启动各种消防设备, 以达到报警及扑灭 火灾的一个系统。其具有容量大、可靠性高、反应迅速等特点。它配合站 场的视频监控系统及站场主控系统可以有效提高消防安全管理的可靠性。

2.2 建立健全管理标准及制度, 落实安全责任

一是落实消防安全管理制度, 加强消防档案的管理, 建立消防的组织 机构, 明确责任落实。严格执行设备的定期检验检查规定和报废标准等, 按照操作规程对设备进行维护保养和操作, 做到 “设施、装备、培训、管
理” 四个到位。健全消防巡查、应急疏散和安全性评价和风险评估等制度, 配备合适和足够的应急疏散设备和防火设施。

二是加强用火、破土、临时用电等施工作业安全管理制度的执行力。 施工作业的违规行为是引发天然气站场火灾爆炸的重要原因, 施工过程必 须严格按照作业程序步骤进行, 即进行作业安全分析、施工单位编制作业 方案、作业方案的审批、施工单位办理进站手续、作业前安全会和HSE培 训、作业前检查、签发作业许可证、作业过程中的监督检查、作业许可的 中断或关闭、作业后评估等。每一项施工作业必须有专门的负责人全程参 与其中。

\section{3 强化消防安全培训}

员工的安全意识和技能是影响消防安全的原因之一, 故加强培训, 提 高员工 “会报警、会疏散自救、会扑救初期火灾” 的 “三会” 能力, 让员 工了解本单位相关消防安全管理制度是提高消防安全管理水平的一个必 要手段。在平时, 天然气输气站场应经常进行消防安全教育, 强化职工的消 防安全意识, 尽量聘请专业人员讲解消防安全最新常识及经验, 增强员工 的消防安全素质。另外还要定期进行消防实战演习, 提高员工的动手能力 和应急处置能力。在演练中发现问题修正预案, 使预案贴近实际, 提高处置 事故的整体能力, 一旦发生事故, 能有效处置, 最大限度的减少人员伤亡和 财产损失。

\section{3 结语}

消防安全工作责任重于泰山, 做好消防安全工作非一日之功, 它是一 项长期的、复杂的系统工程, 需要不断探索、巩固和创新, 最终走出一条适 合自身安全、操作性强的管理路子。时刻保持良好的、稳定的安全生产局 面, 做到筑牢防线、长抓不懈、警钟长鸣是天然气输气行业的一项重大工 程。对于天然气输气站场的消防安全管理必须努力贯彻 “预防为主、防消 结合” 的方针, 从全局出发、统筹兼顾、保障安全、方便使用、经济合理, 不断总结经验教训, 努力从人的不安全行为、物的不安全状态、环境因素 和管理上的缺陷等方面入手, 方能确保站场的安全平稳运行。

[参考文献]

[1]赵秀雯,于力,柴建设.天然气管道安全 $[M]$. 北京:化学工业出版 社,2013.01.

[2]王兴库.油气储运防火安全分析及预防 [J]. 化工管 理,2007,(08):40-42.

[3]解智堂. 石油天然气站场安全管理工作探讨 [J]. 石油和化工设 备,2011,14(11):56-57.

作者简介:

祝原林(1986--), 男,四川南充市人,汉族,大专,注册消防工程师、注 册安全工程师。研究方向：建筑消防安全。 